\title{
MOEDERTAALONDERRIG IN 'N DEMOKRATIESE SUID-AFRIKA
}

\section{Anne-Marie Beukes}

Die vraag of moedertaalonderrig in 'n demokratiese, veeltalige Suid-Afrika wenslik en haalbaar is, gaan een van die belangrikste taalonderwysbeplanningskwessies van die toekoms wees. In hierdie artikel word aangevoer dat 'n indringende histories-strukturele analise van die taalonderwysbeleid van die Apartheid Suid-Afrika ' $n$ voorvereiste vir 'n sinvolle gesprek oor hierdie kwessie is.

Die vooroordeel teen moedertaalonderrig in ons konteks moet gesien word as 'n erflating van ons linguisistiese taalbeleid van die verlede. 'n Nuutgedefinieerde moedertaalonderrigbeleid waardeur taalongelykheid uitgeskakel kan word, is noodsaaklik. 'n Sentrale argument van die artikel is dat ' $n$ verbintenis tot moedertaalonderrig ' $n$ verbintenis tot basiese menslike taalregte en daarom tot ware demokrasie is.

The question whether mother tongue education is desirable and feasible in a democratic, multi-lingual South Africa is one of the most important educational planning issues of the future. This article avers that an in-depth historical-structural analysis of the language teaching policy of Apartheid South Africa is a pre-requisite for a meaningful discussion on this issue.

The prejudice against mother tongue education in our context should be seen as a legacy of the language policy of the past. $A$ newly defined mother tongue education policy which eliminates language inequality is needed. A central argument of the article is that $a$ commitment to mother tongue education is a commitment to basic human language rights and thus to true democracy.

\section{Inleiding}

In die Suid-Afrikaanse onderwyskonteks was taal nog altyd 'n sentrale kwessie. In apartheid Suid-Afrika het dit immers 'n lang en kontroversiële (en veelal bitter) geskiedenis, veral wat die moedertaal as die medium van onderrig betref. Juis vanweë die ideologiese kleur wat aan die beginsel van moedertaalonderrig in ons samelewing kleef, is dit stellig voor die hand liggend dat dit een van die belangrikste onderwyskwessies is wat in die onderhandelings- en uiteindelik ook die taalbeplanningsgesprek vir 'n demokratiese Suid-Afrika aan die orde moet kom.

Om hierdie verwikkelde gesprek te kan voer, gaan dit van groot belang wees dat die deelnemers 'n behoorlike insig het in die sosiale en ideologiese kragte wat in die verlede 'n bydrae gelewer het tot enersyds die aanvaarding en ondersteuning van die moedertaalbeginsel, maar andersyds ook tot die verwerping daarvan. Dit is daarom 'n sentrale tese van hierdie bydrae dat ' $n$ indringende histories-strukturele ontleding van die taalbeleid in ons apartheidsamelewing 'n noodsaaklike vertrekpunt is vir sinvolle gesprek oor die wenslikheid al dan nie van onderrig in die moedertaal. Ek argumenteer dat 'n behoorlike begrip van die dinamiek van ons samelewing waarin 'n diskriminerende taalbeleid in die verlede kon botvier en die beginsel van moedertaalonderrig tot kontroversie gebring is, ons uiteindelik moet uitbring by die formulering en uitvoering van 'n haalbare demokratiese taalplan vir die toekomstige Suid-Afrika. 


\section{Taalbeleid in apartheid suid-afrika}

Die debat oor moedertaalonderrig kan dus nie losgemaak word van die breër, oorsaaklike konteks van ons diskriminerende taalbeleid van die verlede nie. 'n Historiese analise van postkoloniale taalbeleid in Suid-Afrika toon aan dat geen regeringstaalbeleid sedert die eerste besetting deur Nederland in 1652, die opeenvolgende Britse besettings tot die huidige bestel ooit die feit behoorlik verreken het dat Suid-Afrika in wese 'n veeltalige land is nie. Die taalbeleid van verskillende Suid-Afrikaanse regerings wat deur die loop van vier eeue gevolg is, het onteenseglik, soos Van den Berghe (1990: 56) daarop wys, telkens slegs die belange van die regerende elite gedien:

The policy was simply, assure the dominance of the language of those who control the state, first Dutch, then English, and lastly Afrikaans.

Die Suid-Afrikaanse samelewing is dus van vroeg reeds as't ware linguisties gedetermineer, 'n situasie wat gewoon voortgeduur het in die twintigste-eeuse SuidAfrika. Ten spyte van die de facto veeltalige aard van ons samelewing is 'n amptelike tweetalige taalbeleid sedert die vroegste jare van hierdie eeu gevolg. Die taalbehoeftes van slegs 'n sekere deel van die Suid-Afrikaanse samelewing is gedien. Kortom: die doelwit met hierdie taalbeleid het veelal gesentreer rondom die konsolidering van mag en die fasilitering van kommunikasie tussen die owerheid en sy wit burgers.

Soos so vele ander Afrika-lande, vertoon die linguistiese kaart van Suid-Afrika 'n merkwaardige kompleksiteit met die nagenoeg 25 tale wat hier gebruik word. Tans word 12 sg. "hooftale" onderskei waarvan slegs Engels en Afrikaans ampstatus het. Die sprekers van die twee amptelike tale vorm maar bykans 'n kwart $(24,34 \%)$ van die bevolking. Die meerderheid van die bevolking, nagenoeg 'n driekwart $(73,27 \%)$, is sprekers van 'n Afrika-taal met Zulu (21,61\%) en Xhosa $(17,44 \%)$ as die grootste hiervan. Die hibridiese verkeerstale wat op groot skaal in die metropolitaanse gebiede deur swart mense gebruik word, is egter nie in hierdie statistiek verreken nie. Naas enkele Asiatiese tale (Tamil, Telegu, Gujerati, Urdu en Hindi), word nagenoeg ses Europese tale en Kantonees ook deur 2,26\% van die bevolking gebruik (Webb 1991).

Die gebrek aan kongruensie tussen die amptelike taalbeleid en die belange van al die inwoners van ons land het gelei tot verreikende linguistiese ongelykheid en eksploitasie. Die bevoorregting van die uitheemse, koloniale taal, Engels, en slegs één van die 11 groot inheemse tale, Afrikaans, het onvermydelik gelei tot ernstige taalagtergesteldheid vir die oorgrote meerderheid van die land se mense. Deur middel van hierdie gebrekkige taalbeleid kon die owerheid, om in Habermas se terme te praat, hierdie mense se lewens ook linguisties "kolonialiseer" (vgl. Fairclough 1989: 197). Die taalbeleid van postkoloniale Suid-Afrika, en in die besonder ook twintigste-eeuse SuidAfrika, het dus politieke mag en die bestendiging daarvan betekenisvol help hanteer.

My voorkeur: Vervolgens word die grondslae van hierdie linguistiese ongelykheid in Suid-Afrika uitgelig aan die hand van die teoretiese konstruk van linguisisme soos ontwikkel deur Skutnabb-Kangas (1988) en ook Phillipson (1988). Die teorie van linguisisme stel ' $n$ mens in staat om nie slegs die koppeling tussen taalbeleid en sosiopolitieke magstrukture te verduidelik nie, maar kan die allerbelangrike waardes en houdings binne ons samelewing wat taalimperialisme gelegitimeer en in 'n sekere sin as gangbare praktyk verduur het, ook besonder vrugbaar blootgelê word.

\subsection{Die begrip "linguisismen}

Linguisisme is volgens Skutnabb-Kangas (1988: 13) verwant aan

the other negative -isms: racism, classism, sexism, ageism. Linguicism can be defined as ideologies and structures which are used to legitimate, effectuate and reproduce an unequal division of 
power and resources (both material and non-material) between groups which are defined on the basis of language (on the basis of their mother tongues).

Linguisisme is nie 'n onbekende verskynsel in sowel koloniale as postkoloniale Afrika nie. In die onafhanklikheidsdrif van die na-oorlogse Afrika het die meeste van die nuutbevryde state die uitheemse, koloniale taal (of Engels, of Frans, of Portugees) as amptelike taal "gekies" oënskynlik omdat die inheemse tale van die betrokke lande indertyd nie as geskik geag is vir die uitvoering van regeringsake of vir die onderwys nie. Maar op die keper beskou, is hierdie taalbeleid eintlik polities ingegee en operasioneel gerig deur die hegemonie van die koloniale tale en ondersteun deur 'n Westers geïnspireerde "eentaligheidsideologie" waarvolgens veeltaligheid ten alle koste vermy behoort te word. Linguistiese minderheidsgroepe (ironies juis die inheemse taalsprekers) is: natuurlik deur hierdie taalbeleid grootliks openbare diskoersmoontlikhede in die massamedia, regering, ens. ontsê. Die meganisme van linguisisme is ideologies kragtig en verreikend in dié sin dat eentaligheid as gangbare praktyk, as "gesonde verstand", voorgehou word:

When minority languages do not appear in these areas of public discourse, their exclusion comes to be seen as natural and inevitable (Tollefson 1991: 12).

In die konteks van Afrika het linguisisme dus aantoonbaar 'n besonder effektiewe meeloper van politieke en ekonomiese mag geword.

\subsection{Die omvang van linguisisme in Suid-Afrika}

Linguisisme kom in verskeie gedaantes in 'n samelewing voor. Van die heel vroegste aanduidings van overte linguisisme in twintigste-eeuse Suid-Afrika is te vinde in die Uniekonvensie van 1909 waar taalkwessies tydens die onderhandelinge prominent gefigureer het bloot in soverre net Engels en Hollands beskerm moes word. Die belange dus van slegs 'n spesifieke groep, nl. die wit burgers is hier vooropgestel ten koste van die meerderheid inwoners van die toekomstige Unie van Suid-Afrika. Maar hierdie grondwet sou ook die matrys word waarvolgens lateres gemodelleer is, nl. die Grondwet van die Republiek van Suid-Afrika, Wet nr. 32 van 1961 en ook die onlangse Wet nr. 110 van 1983 met die enigste wesentlike verskil dat Hollands in albei deur Afrikaans vervang is. 'n Addisionele verskil in die jongste grondwet is artikel 89(3) waarin toegelaat word vir die erkenning van sekere inheemse tale binne die sg. selfregerende gebiede van SuidAfrika.

Daar word bereken dat bykans $80 \%$ van die Suid-Afrikaanse bevolking nie een van die twee amptelike tale goed genoeg beheers om te kan deelneem aan die administrasie en ekonomie van die land nie (Van Rensburg 1991; Ndebele 1991). Die gevolge van hierdie taalagtergesteldheid was vir die sprekers van die inheemse tale verreikend en het hulle benadeel in terme van hulle toegang tot politieke en administratiewe instellings van die land. Hulle kommunikasie met die staatsapparaat, regspleging, onderwys en ook werksgeleenthede is negatief geraak. Hierdie sprekers is bv. gelyke toegang tot hoër professionele poste ontsê, en, van kardinale belang, hulle is effektief uitgesluit van betekenisvolle deelname aan die nasionale politieke prosesse. Overgezet sijnde: ons linguisistiese taalbeleid het hierdie sprekers effektief weerhou van "discoursal positions of power" (Fairclough 1989: 63).

Met die term "minderheid" word hier nie bedoel groeperinge wat getalsgewys 'n minderheid vorm nie, maar juis diegene wat relatief minder mag, regte en voorregte as die dominante groep(e) in 'n samelewing het. Vanselfsprekend is hierdie betekenis van die term ook van toepassing op die situasie van die inheemsetaalsprekers in apartheid Suid-Afrika (met die uitsondering van een groep inheemse taalsprekers, die wit Afrikaanssprekendes wat as 'n dominante groep uitgesproke meer mag, regte en voorregte geniet het). 
Koverte linguisisme kom ook in ons samelewing voor in dié sin dat sekere tale in sekere domeine de facto eenvouding nie gebruik word nie alhoewel die gebruik daarvan sekerlik ook nie verbied is nie. Die selektiewe konstitusionele steun vir Engels en Afrikaans het 'n ernstige uitwerking gehad op die funksies en domeine van die ander inheemse tale, asook, en dit vind ek 'n ernstige kwessie, op die houding van die betrokke taalagtergestelde gemeenskappe jeens dié tale. Volgens gegewens uit die onlangse LiCCA (SA)-projek word nie 'n enkele Afrika-taal as kommunikasiemedium gebruik in die wêreld van hoëre finansies soos die effektebeurs, maatskappyverslae, kontrakte, ens. nie; maar eweneens ook nie in skoolhandboeke as medium van onderrig op sekondêre en tersiêre vlak, behalwe taalvakke nie (Webb 1991). Die ideologie van linguisisme in Apartheid Suid-Afrika het dus berus op die hegemonie van Engels en Afrikaans.

Die uitvloeisel van hierdie koverte linguisisme, nl. taalvooroordeel en gebrekkige taalvitaliteit ook by die taalagtergestelde gemeenskappe van Suid-Afrika toon duidelik die omvang van die destruktiewe mag van linguisisme. Dus: ons eksklusiewe taalbeleid met die gepaardgaande hoë status van Engels en Afrikaans het onvermydelik tot gevolg gehad dat die ander inheemse tale funksioneel tot 'n lae status gerelegeer is; maar die kardinale punt hier is dat selfs die inheemse taalsprekers daaraan meedoen. Hierdie situasie is weer eens nie vreemd aan postkoloniale Afrika nie (Tollefson 1991: 291):

\begin{abstract}
The hegemony of English (en in die konteks van Apartheid SuidAfrika ook Afrikaans - A-MB), or of other languages, is not merely tolerated by the 'developing' world; it is considered a legitimate model for society. In many newly independent states, a tiny Englishspeaking elite controls state policy-making organs while the masses of people remain excluded.
\end{abstract}

Geoordeel aan die taalbeleid wat in Afrika se jongste onafhanklike staat, Namibië, aanvaar is, word die juk van linguistiese ongelykheid in Afrika moeiliker geïdentifiseer en afgewerp as die staatkundige. Du Plessis (1991: 8) sê die volgende oor die linguisistiese rol van Engels in dié land:

\title{
Engels vervul in hierdie proses (van magskonsolidasie - A-MB) 'n belangrike kontrolemiddel - dié wat hulle nie daarin kan bedien nie word uitgesluit en kan voorlopig nie hierdie magsproses in die wiele ry nie.
}

By die inheemse taalgemeenskappe in Suid-Afrika is daar tot nog toe weinig beduidende aandrang op hulle basiese taalregte ${ }^{*}$. As slagoffers van linguisisme is hulle as groep "linguisties gedetermineer" oftewel "gekolonialiseer" en is hulle tale funksioneel gerelegeer tot die domeine van slegs die huis, woonbuurt en kerk. Daar word 'n prestigewaarde aan Engels gekoppel as die (enigste) toegang tot onderwys, wetenskap en die internasionale wêreld. En dit nieteenstaande die feit dat die aandrang dat individue die reg het om hulle moedertaal onder meer in die onderwys en in kommunikasie met die staatsapparaat te gebruik, volgens Tollefson (1989) júís 'n effektiewe strategie teen linguisisme kan wees. Die idealisering van die dominante groep en hul taal met die gepaardgaande stigmatisering van die gedomineerde groep en taal is 'n kragtige en destruktiewe ideologiese meganisme.

Overte linguisisme lê ook ten grondslag aan taalbeleid in die onderwys in Suid-Afrika. Die tradisie waarin 'n nie-inheemse taal as medium van onderrig in swart onderwys gebruik is, word, soos elders in Afrika en ook Indië, teruggevoer na die sendingskole van die negentiende eeu waar sowel Amerikaanse as Britse sendelinge deur medium van

'n Inherente voordeel aan 'n histories-strukturele analise van taalbeleid is dat kollektiewe gedrag as 'n eenheid van analise benut kan word om kwessies soos taalhoudings (wat tradisioneel eerder in psigolinguistiese verband bestudeer is) in 'n samelewing te beskrywe as 'n teorie van menslike gedrag. Mense se handelinge word dus volgens hierdie benadering beoordeel in terme van hulle verbintenis met 'n sosiale groep, hetsy sosiale klas, geslag, ens. 
Engels gepreek en onderrig het (Phillipson 1988). Die koppeling tussen overte linguisisme en die onderwys word soos volg deur Phillipson (1988: 344 ) verwoord:

In colonial societies, education determined access to influence, and in education "English ... was the real key to success".

Ook in Suid-Afrika het die bevordering van Engels as vak en as medium van onderrig prominent gefigureer in die taalbeleid van sendingskole (Steyn 1980; Reagan 1987a; Hartshorne 1987). Dit is inderdaad sedert 1841 as voorwaarde gestel vir staatsondersteuning van hierdie skole (Hartshorne 1987). Gevolglik het die onderrig van die inheemse swart tale in die sendingskole weinig aandag gekry sodat hulle volgens Lanham (1978: 22-3)

\begin{abstract}
trained and educated a Black elite thus providing an authentic cultural context for English ... The scholarly missionaries educated a group of men and women with high competence in English, a deep insight into the world of English ideas and values, a strong loyalty to English and a sense of the 'great tradition' of English literature (hence the devotion and attachment to Shakespeare and the poets which continue to the present day).
\end{abstract}

$\mathrm{Na}$ Uniewording in 1910 is die beleid van Engels as onderrigmedium in regeringsondersteunde skole voortgesit, alhoewel die belang van moedertaalonderrig volgens Hartshorne (1987) tog geleidelik in Natal en ook later in die Kaapprovinsie begin posvat het. Vir die eerste twee skooljare in die Transvaal en in Natal die eerste ses skooljare is leerlinge tot in die vroeë vyftigerjare in hulle moedertaal onderrig waarna een van die ampstale (feitlik deurgaans Engels) as onderrigmedium gebruik is (Hartshorne 1987).

'n Waterskeidingsrif in die onderwys in Suid-Afrika is die aanvaarding in 1953 van die Wet op Bantoe-Onderwys waarvolgens swart mense se onderwys deur 'n aparte departement bestuur sou word. Die belangrikste dryfveer vir die instel van hierdie wetgewing was konsolidering van mag. Moedertaalonderrig was die hoeksteen van die ideologie van Christelike Nasionale Onderwys (CNO) waardeur ras- en taalgesegregeerde onderwys bewerkstellig moes word. Afrikaans is na die aanvaarding van die Wet op Bantoe-Onderwys op 'n $\mathrm{sg}$. 50/50-grondslag naas Engels as 'n medium van onderrig in swart sekondêre skole afgedwing. Afrikaans is vervolgens toenemend verbind aan die owerhede se diskriminerende beleid en is gestigmatiseer as die "taal van die verdrukker". Na die Soweto-opstande in 1976 is Afrikaans op beduidende skaal deur die swart gemeenskap as onderrigmedium verwerp.

Die Afrikaner se taalimperialisme herinner sterk aan dié van die Britse bewind van die vorige eeu toe

political and economic reasons had laid down, from Grey through to Milner, that English was a sine qua non for state aid in education (Hartshorne 1987: 65).

Maar Engels het grootliks daarin geslaag om sy mag in Suid-Afrika te konsolideer en die kleed van "koloniale taal" af te werp. Dit wil voorkom asof dit die swart bevolking se (onbewuste?) houding is dat Engels, eerder as 'n eie, inheemse taal, die instrument is waarmee aan die "verdeel en heers"-ideologie van die apartheidsdenke ontsnap kan word. Veelal a.g.v. die manipulasie van Afrika-etnisiteit in terme van "stamgebondenheid" in Apartheid Suid-Afrika het etnisiteit mettertyd, en daarmee saam die inheemse tale as markante weerspieëling van etniese identiteit, onder die swart gemeenskap funksioneel gestigmatiseer geraak. Trouens, baie swart Afrikane het in die verlede hulle etnisiteit ontken as artikulasie van hulle teenkanting teen die apartheidsideologie (Van den Berghe, 1990). 
Uiteraard kan die taalagtergesteldheid van die inheemse taalsprekers gekoppel word aan die linguisisme in Apartheid Suid-Afrika. Ook aan hul daarmee gepaardgaande sosiopolitieke agterstelling en die gebrekkige institusionele steun (soos ontoereikende befondsing vir vaktaalontwikkeling, ens.) wat die tale in terme van ons linguisistiewe taalbeleid geniet het (Fishman 1987 en Swanepoel \& Morris 1988). Maar die negatiewe houding van die sprekers tot die intrinsieke en funksionele waarde van hul moedertaal is in der waarheid 'n gefossileerde linguisisme wat veroorsaak dat die volle bestek van historiese en strukturele magte wat 'n ongelyke taalbeleid in ons samelewing kon afdwing, nie gekonfronteer word nie. Tollefson (1991:210) waarsku juis:

\section{Language education professionals must reject the notion that learning a language is an ideologically neutral act intended simply to develop an employment skill. That some people must learn English (en in ons konteks ook Afrikaans $-A-M B$ ) to get a job is a result of unequal relationships of power - not a solution to them.}

Die oorheersing van 'n taal/tale op die arbeidsterrein in Apartheid Suid-Afrika is dus nie net 'n erflating van ons linguisistiese taalbeleid nie, maar júís 'n regstreekse meganisme daarvan. Dit is nie haalbaar om hier te argumenteer dat dit eenvoudig gaan om die realiteit van die "markwaarde" van 'n taal/tale nie (met die implikasie dat ongelykheid en oorheersing nie werklik ter sake is nie). Die sg. "botter-en-broodwaarde" van Engels en Afrikaans is te herlei na die ideologie van linguisisme, naamlik dat dominansie van hierdie tale toegang tot (en gevolglik beheer oor) die werkplek bewerkstellig en sodoende ekonomiese en politieke mag in die hande van die sprekers van die dominante tale verseker.

Die houdings wat 'n samelewing teenoor taal en taalkwessies het, kan 'n bepalende rol speel in die tipe taalbeleid en onderwys waarop daardie samelewing aandring. Daar word wyd aanvaar, alhoewel sonder omvattende empiriese getuienis, dat Engels as medium van onderrig hoog aangeslaan word deur die swart gemeenskap, veral in sekere streke soos bv. KwaZulu (Chick \& Seneque 1987). Die swart gemeenskap huldig oënskynlik verskillende sienings oor die rol en waarde van die inheemse tale as onderrigmedium. Enersyds is daar diegene wat ten gunste is van die gebruik van hierdie tale op skool (vgl. Schuring 1977; Khiba 1990 \& 1991). Andersyds is daar ook teenstanders van die gebruik van die inheemse tale op skool

since their use has been seen as yet another device to ensure that black South Africans remain 'hewers of wood and drawers of water' (Reagan 1987a: 3).

Hierdie taalhouding berus op die onjuiste aanname dat die inheemse tale intrinsiek "primitief" is en nie as kommunikasiemiddel in 'n moderne tegnologiese samelewing kan dien nie. So 'n siening is die gevolg van 'n gefossileerde linguisisme wat deur linguisties gefundeerde opvoeding en werklike taaldemokrasie geëlimineer kan word.

\section{Moedertaalonderrig in 'n veeltalige, demokratiese samelewing}

Taaldemokrasie is die enigste wyse waarop minderheidstaalregte in 'n veeltalige samelewing nie slegs gerespekteer nie, maar inderdaad teen die vloedgolf van die hoofstroom beskerm kan word. Kortom: taaldemokrasie is die effektiewe teenvoeter vir linguisisme.

Omdat onderwys nooit in 'n vakuum plaasvind nie, maar veel eerder 'n manifestasie van die breër samelewingsorde en -dinamiek is, sal die kwessie van medium van onderrig in 'n toekomstige, demokratiese bestel in Suid-Afrika waarin geïnstitusionaliseerde rassisme en linguisisme maksimaal geëlimineer behóórt te wees, indringend aandag verdien. 


\subsection{Die begrip "moedertaal"}

In 'n veeltalige samelewing waarin mense vryelik assosieer, kan 'n enkelvoudige opvatting van die begrip "moedertaal" as die taal wat aan moedersknie geleer word natuurlik nie deug nie. 'n Bruikbare perspektief op die begrip is dié van SkutnabbKangas (1988). Sy gebruik vier kriteria om die moedertaal te definieer, naamlik volgens

(i) oorsprong: die taal wat jy eerste geleer het;

(ii) vaardigheid: die taal wat jy die beste verstaan;

(iii) funksie: die taal wat jy die meeste gebruik; en

(iv) identifisering:

- die taal waarmee jy identifiseer

- die taal waaraan ander jou as 'n moedertaalspreker verbind.

Die waarde van Skutnabb-Kangas se omskrywing is veral geleë in die ruimte wat vir die individu gelaat word om inderdaad meer as een moedertaal te kan hê en daarbenewens om ook 'n verskuiwing van moedertaal te ondergaan afhangende van lewensomstandighede. Dit is immers 'n realistiese opvatting van die waarde van taal as 'n funksionele kommunikasiemiddel in 'n heterogene, veeltalige samelewing.

\subsection{Moedertaalonderrig en taaldemokrasie}

Die besluit oor die medium waarin onderrig in ' $n$ land se skole moet geskied, is een van die belangrikste taal- en onderwysbeplanningsbesluite wat 'n land moet neem. 'n Rigtinggewende, maar tegelyk ook kontroversiële uitspraak oor hierdie kwessie is die UNESCO-verslag van 1953 en 1968 waarin aanbeveel word dat die leerling se moedertaal as onderrigmedium gebruik moet word vanaf die aanvang van skoolopleiding en dit vir so lank moontlik volgehou moet word. UNESCO regverdig sy standpunt uit 'n psigolinguistiese perspektief (die moedertaal is die tekensisteem wat mentaal die beste vir sowel ekspressie as resepsie is); 'n sosiolinguistiese perspektief (die moedertaal is 'n instrument vir identifisering met die ter sake eie gemeenskap), asook 'n opvoedkundige perspektief (die kind leer vinniger deur middel van die moedertaal).

Daar word tans hoog opgegee oor demokrasie en die bemagtiging van mense in 'n toekomstige Suid-Afrikaanse samelewingstruktuur. 'n Belangrike gevolgtrekking waartoe die argument oor die waarde van onderrig in die moedertaal en die gevolglike geïnstitusionaliseerde gebruik van die moedertaal ons voer, is dat 'n verbintenis tot demokrasie sonder twyfel ook 'n uitgesproke verbintenis tot taalregte is (Tollefson 1991: 211):

A commitment to democracy means that the use of the mother tongue at work and in school is a fundamental human right. This perspective differs from the use of the mother tongue as an expression of ethnicity, which separates language from questions of power and domination. Instead, this perspective views language as parallel to race, gender, and other factors as deserving of legal protection, and it measures social justice by the extent to which societies ensure that individuals may use their mother tongues for education and employment. 


\section{Ten slotte}

In die konteks van $\mathrm{CNO}$ en Bantoe-Onderwys en die gevolglik linguisisties geïnspireerde taalonderwysbeleid is die skool in die verlede aangewend as 'n politieke instrument waardeur die apartheidsideologie ondersteun moes word. Maar ten behoewe van 'n demokratiese, antilinguisistiese samelewing sal die skool as instelling in die toekomstige Suid-Afrika eerder benut moet word as een van die belangrike agente van sosiale verandering. 'n Groter verdraagsaamheid vir linguistiese en kulturele heterogeniteit sal gekweek moet word:

All education worthy of the name is multicultural. It should be part and parcel of education generally to show an awareness of diverse cultures and to develop an appreciation of human difference (Edwards 1985: 131).

Die enkelmedium-onderrigmodel van die verlede waardeur taal- en kulturele fragmentasie bewerkstellig is, kan duidelik nie aan die vereistes van ons toekomstige samelewing voldoen nie. Gesien teen die ongelukkige gevalsgeskiedenis van moedertaalonderrig as onlosmaaklike deel van 'n destruktiewe, linguisistiese taalbeleid in Apartheid Suid-Afrika, is dit van die allergrootste belang dat 'n nuutgedefinieerde moedertaalbeleid vir ons toekomstige onderwysbedeling onderhandel moet word. Die onbetwisbare meriete van onderrig deur middel van die moedertaal is ondermyn deur die ideologiese ambisies van CNO en Bantoe-Onderwys.

Daar word tans gespekuleer oor onder meer die wenslikheid van byvoorbeeld twee- of ook multitalige onderwysmodelle vir 'n demokratiese Suid-Afrika (Alexander 1990). Maar wat die presiese konfigurasie van die model waarop uiteindelik besluit word ook al sou wees, is my argument dat die sentrale rol van onderrig deur die moedertaal daarin verreken sal móét word:

The mother tongue can be emphasized partly in its own right, as a self-evident human right, and partly in order to be able to give a better instrument for coping with both the learning of the second language and the learning of other skills, and to include analysis, understanding, evaluation and action in relation to societal questions of economic and political power (Skutnabb-Kangas en Cummins 1988: 394).

Demokrasie berus immers op die bemagtiging van mense en dis vermoedelik veral deur die moedertaal dat mense ingrypend en betekenisvol bemagtig word. 
Verwysings

AFRICAN NATIONAL CONGRESS. 1990. Language Workshop Report, 21-24 Maart 1990, Harare.

ALEXANDER, Neville. 1990. Afrikaans en taalonderrig in 'n vrye Suid-Afrika. In Die Suid-Afrikaan, Oktober/November, 38-39.

BEUKES, Anne-Marie. 1991a. Afrikaans in formal education. In Webb, Victor $\mathrm{N}$ (Red.), Research Report for The First International LiCCA Conference, 57 April 1991, Universiteit van Pretoria. Pretoria: Universiteit van Pretoria.

BEUKES, Anne-Marie. 1991b. The politics of language in formal education: the position of Afrikaans. In Tydskrif vir Taalonderrig, 25(1): 64-77.

CHICK, K \& M SENEQUE. 1987. The role of the applied linguist in language planning: the medium of instruction problem in KwaZulu, Natal. In Young, Doug (Red.), Language: planning and medium in education. Rondebosch: The Language Unit and SAALA, 120-135.

DU PLESSIS, Theo. 1991. Die taal van demokrasie. In Democracy in action. Journal of IDASA, 15 Oktober, 8-9.

EDWARDS, J. 1985. Language, society and identity. Oxford: Blackwell.

FAIRCLOUGH, Norman. 1989. Language and power. New York: Longman.

FISHMAN, Joshua A. 1987. Research on national languages. In Ammon U, N Dittmar \& KJ Mattheier (Reds.), Sociolinguistics. Berlyn: Walter de Gruyter, 638-646.

HARTSHORNE, Ken B. 1987. Language policy in African education in South Africa, 1910-1985, with particular reference to the issue of medium of instruction. In Young, Doug (Red.), Bridging the gap between theory and practice in English second language teaching. Kaapstad: Maskew Miller Longman, $62-81$.

KHIBA, K. 1990. A language attitude survey assessing the attitudes of Bophuthatswana teachers and pupils in the Western Cape. Universiteit van Kaapstad: ongepubliseerde $\mathbf{B}$. Ed-studie.

KHIBA, K. 1991. Die bepaling en beskrywing van 'n geselekteerde groep leerlinge van die Dr AT Moreosele High School, Mabopane, Pretoria se houding teenoor Setswana en Engels. RAU: ongepubliseerde M.A. (Taalonderrig) -studie.

LANHAM, LW. 1978. An outline history of the languages of Southern Africa. In Lanham, LW \& KP Prinsloo (Reds.), Language and communication studies in South Africa. Kaapstad: UOP, 13-28.

NDEBELE, NS. 1991. Questions and answers about the ANC language policy. Referaat gelewer by The First International LiCCA Conference, 5-7 April 1991, Universiteit van Pretoria.

PHILLIPSON, Robert. 1988. Linguicism: structures and ideologies in linguistic imperialism. In Skutnabb-Kangas, Tove \& Jim Cummins (Reds.), Minority Education. Clevedon: Multilingual Matters, 339-358. 
REAGAN, Tim. 1986. Taalbeplanning in die Suid-Afrikaanse onderwys: 'n oorsig. In Tydskrif vir Taalkunde, 4(1): 32-46.

REAGAN, Tim. 1987a. Language policy and black education in South Africa. In Journal of Research and Development in Education, 20(2): 1-13.

REAGAN, Tim. 1987b. Ideology and language policy in education: the case of Afrikaans. In Du Plessis, Hans \& Theo du Plessis (Reds.), Afrikaans en taalpolitiek: 15 opstelle. Pretoria: HAUM, 133-139.

SCHURING, GK. 1977. Afrikaans en Engels onder Swartmense in die RSA, Deel 2. Pretoria: RGN.

SKUTNABB-KANGAS, Tove. 1988. Multilingualism and the education of minority children. In Skutnabb-Kangas, Tove \& Jim Cummins (Reds.), Minority Education. Clevedon: Multilingual Matters, 9-44.

SKUTNABB-KANGAS, T \& J CUMMINS. 1988. Concluding remarks: language for empowerment. In Skutnabb-Kangas, Tove \& Jim Cummins (Reds.), Minority Education. Clevedon: Mutlilingual Matters, 390-394.

STEYN, JC. 1980. Tuiste in eie taal. Die behoud en bestaan van Afrikaans. Kaapstad: Tafelberg.

SWANEPOEL, Piet $H \&$ Rose MORRIS. 1988. Die rekenarisering van terminografiese prosesse. TERMNET-projek in die LEXINET-program. Pretoria: RGN.

TOLLEFSON, James W. 1991. Planning language, planning inequality. Language policy in the community. New York: Longman.

VAN DEN BERGHE, Pierre L. 1990. Language and politics in South Africa: A response to Neville Alexander. In SA Sociological Review, 3(1): 56-61.

VAN RENSBURG, Christo MJ. 1991. Language planning in the African context: a South African perspective. Referaat gelewer by The First International LiCCA Conference, 5-7 April 1991, Universiteit van Pretoria.

WEBB, Victor N. 1991. Language planning for a post-apartheid South Africa. Information Booklet for The First International LiCCA Conference, 5-7 April 1991. Pretoria: Universiteit van Pretoria. 